\title{
Evaluation of the Effectiveness of Pusat Pembinaan Profesi Keuangan Supervision of CPAs and Public Accounting Firms
}

\author{
Dewi Hariyani \\ Accounting Department, Economics and Business Faculty \\ Universitas Indonesia \\ Jakarta, Indonesia \\ dewi.dewiarimbi.arimbi@gmail.com; lwondabio@gmail.com
}

\author{
Ludovicus Sensi W \\ Accounting Department, Economics and Business Faculty \\ Universitas Indonesia \\ Jakarta, Indonesia \\ sensi@pertamina.com
}

\begin{abstract}
This research aims to evaluate the effectiveness of the supervision performed by Pusat Pembinaan Profesi Keuangan (PPPK) over certified public accountants (CPAs) and public accounting firms (firms) in order to determine whether PPPK's supervision guidelines is sufficient compared with guidelines developed by Public Company Accounting Oversight Board (PCAOB) and Accounting and Corporate Regulatory Authority (ACRA). This research is motivated by reports on CPA misconduct regarding incomplete independent auditor's reports where working papers are not provided as well as increased incidences of CPA and firm disobedience regarding regulations, legislation, and professional standards, even though they are supervised by PPPK, who acts as CPA regulator. A qualitative descriptive method is implemented through document observation, interviews, and a literature review. In general, the PPPK's supervision over CPAs and firms can be considered effective. However, this supervision still requires improvement and implementation of inspection guidelines, including consideration of CPAs' and firms' risk analysis through inspection results and improvement of action plan implementation for follow-up and monitoring. The PPPK's inspection guidelines are sufficient when compared with those of PCAOB and ACRA. This research also finds that a lack of inspection personnel leads to overload in the inspection of CPAs and firms.
\end{abstract}

Keywords-effectiveness; inspection; Pusat Pembinaan Profesi Keuangan

\section{INTRODUCTION}

Rapid economic growth has led accounting to become an increasingly critical tool during economic and financial decision-making processes. This requires a company's management to have a better understanding of the financial information disclosed in their financial report. Generalpurpose financial reporting is intended to provide financial information about the reporting entity that is useful to existing and potential investors, lenders, and other creditors when making decisions about providing resources to the entity [1].

Financial statements act as the final process of financial reporting and serve a critical role as a reflection of a company's performance. Financial statements provide information regarding the economic resources owned by the entity and the effect its transactions or other occurrences have on those resources. Therefore, an ideal financial statement should be transparent, accurate, delivered on time, and not deviate from available financial accounting standards.

In order to prepare financial statements that are credible when presented to those statement's users, a company's management requires professional third-party assistance.. Specifically, this third party is a Certified Public Accountant (CPA). CPAs act as a bridge between the shareholders and firm management by providing assistance in increasing financial statement transparency, which acts as a form of management accountability to shareholders. CPAs play an important role in providing assurance to investors and creditors regarding the accuracy of the financial statement prepared by management.

CPAs are expected to provide their services to a professional standard. The quality of their financial statement opinions serves as an index of their professionalism, which is associated with their adherence to regulations and professional standards. According to [2], both internal control tests and substantive tests are able to show an auditor's capacity to detect misrepresentations. On the other hand, their adherence to financial-reporting-related auditing standards reflects their ability to identify and report misrepresentations.

CPAs must comply with and implement standards on auditing (SA) and a professional code of ethics, as well as legislation relating to the services they provide. The SA states that an auditor is obliged to prepare documentation of the audit work paper to support the audit needs of the financial statements [3]. This obligation is discussed by [4] regarding certified public accountants stating that when providing their services, CPAs are obliged to prepare work papers and are responsible for these working papers.

However, this requirement is not always followed. For example, a 2017 inspection shocked the profession. The inspection sample on working paper availability for working years 2015 and 2016, signed independent audit reports (Laporan Audit Independen, LAI) were found to have failed to provide any working papers. The biggest discoveries were that a CPA signed 720 LAIs without providing any inspection working papers and the firm did not report 225 LAIs to the PPPK through the firm's annual report in 2015 [5]. This incident shows that the supervising function over CPAs, firms, and their branches is a matter that requires attention. 
PPPK inspections have found an increase in the number of findings obtained during inspections over the last four years. This shows that the CPA and firms have not fully complied with the applicable professional standards.

These above data highlight the necessity of monitoring CPAs and firms by the Pusat Pembinaan Profesi Keuangan (PPPK) so that the amount of unreported findings does not continue to increase. If the working papers that support financial statements continue to be found incompatible with professional standards, it is feared that the opinions given by CPAs regarding the management's financial statements will have the possibility of misstatement; this in turn means that the information in the financial statements cannot be used as a basis for decision-making. Therefore, the supervisory role of the PPPK is very important.

The Ministry of Finance issues CPA licenses through the PPPK, which acts as regulator with responsibility for preparing policies, as well as training, development, and monitoring CPAs. PPPK is obliged to monitor whether the permits that have been granted are used professionally by CPAs when providing their services, as evidenced by CPAs complying with applicable laws and professional standards.

The PPPK's supervisory function is carried out by the Bidang Pemeriksaan Profesi Akuntansi (BPPA). This unit is responsible for the inspection of the accounting profession, which includes inspection of CPAs, firms, and their branches. To assist in conducting these inspections, BPPA has formulated inspection guidelines formalized through Keputusan Kepala Pusat Pembinaan Akuntan dan Jasa Penilai numbered KEP-4/AP/2015 [6], later revised as KEP17/PPPK/2018 [7].

Based on this background, this research has two main objectives (1) evaluate the effectiveness of PPPK supervision over CPAs and firms, and (2) discover whether the guidelines formulated by the PPPK are sufficient when compared with those developed by the PCAOB and ACRA.

\section{LITERATURE REVIEW}

As a bridge between a firm's shareholders and management, the CPA has the role of enhancing the transparency of financial statements. The CPA's task is to provide assurance regarding the accountability of the information presented in the financial statements. Several theories have been developed about the relationship between a company's management and CPAs in terms of the effort to increase financial statement transparency and laws regulating CPAs, namely (1) agency theory, which discusses agency problems and agency costs, (2) signaling theory, and (3) theories of regulation.

\section{A. Agency Theory}

Improving quality and credibility of an entity's financial statement information can help ensure proper decisionmaking. Accordingly, an entity's business continuity has a strong relation with the agency and principal concept. Principals delegate their authority to an agent. According to [8], agency theory argues for the existence of a contract between the principal and agent. In the context of an enterprise, shareholders (owners) employ managers to operate the company. In this circumstance, the owner acts as the principal and the manager acts as the agent. Principals and agents tend to have different characters. This difference might create a conflict of interest, namely, agency problem. The agency problem forces companies to undertake certain efforts to monitor management's performance. One such effort is relying on CPAs' opinion of the financial statements prepared by the management. In other words, owners hire CPAs to ensure that the financial statements are prepared and presented in accordance with financial accounting standards.

Agency costs are the costs incurred to minimize the agency problem. According to [8], there are three components to agency cost, namely, monitoring costs, bonding costs, and residual loss. Monitoring costs are costs incurred by owners to monitor management's activity in order not to disrupt the owner's welfare. However, such actions are limited to measuring and observing management's behavior. Monitoring includes oversight of budget consumption, compensation policies, operational policies, and audits. Bonding costs are costs incurred by the agent that are binding and limiting to management so as not to harm the owners' welfare. Residual losses are costs arising from the difference in decisions between the owner and management, resulting reductions of the company's wealth.

Based on these three types of cost, the cost relevant to this research is monitoring costs, because management activities must be monitored. One way of conducting such monitoring is with an audit conducted by an external auditor. Thus, an auditor (AP) can reduce the agency problem. The regulator authorized to supervise CPAs is PPPK.

TABLE I. NumBER OF FindingS ON FIRM QUALITY CONTROL SYSTEM (SPM) AND STANDARDS ON AUDITING (SA) IN THE LAST FOUR YEARS

\begin{tabular}{|c|c|c|c|}
\hline \multirow{2}{*}{ Year } & \multicolumn{2}{|c|}{$\begin{array}{c}\text { Number of } \\
\text { Findings }\end{array}$} & \multicolumn{2}{|c|}{ Description } \\
\cline { 2 - 4 } & $\boldsymbol{S P M}$ & $\boldsymbol{S A}$ & \\
\hline 2014 & 202 & 95 & findings were mostly related to \\
2015 & 155 & 270 & \\
2016 & 174 & 516 & \\
2017 & 205 & 604 & \\
\hline
\end{tabular}

\section{B. Signaling Theory}

Signaling theory is employed in this research because of its close relation with financial statement disclosure and the role of external auditor in examining financial statement quality. According to [9], managers can use several approaches to communicate the quality of financial statements. Signaling theory classifies these signals into two large groups: (1) a direct signal. which is reflected in the financial statement, and (2) an indirect signal, which is reflected in the information about amounts of retained equities, quality of external auditors, accounting policies chosen, equity structure, dividend policies, and other information outside the financial statements. An external auditor opinion is needed to reduce uncertainties in financial statement utilization. To fulfill their role properly, these external auditors (CPAs) shall have good audit quality. Company managers do not employ good quality auditors if the company is not in stable condition.

\section{Theories of Regulation}

Well-formulated regulations by the government are necessary to protect the public's interest. The CPAs' role is 
crucial in accounting, especially to provide statements of fairness of financial statements; therefore, the profession needs to be regulated. [9] suggested two theories of regulation: (1) public interest theory, suggesting that regulations should maximize social welfare, and (2) interest group theory, suggesting that regulation is a form of statement of opinion by a group that has interests in line with those of the government. Public interest theory posits that regulations arise from society's desire to fix market failures. This theory assumes that the regulator will side with the public interest. In this case, an independent actor (auditor) is essential to reduce regarding financial statement information asymmetry between the management, investors, and other financial statement users. Therefore, regulations to protect the CPA profession are necessary to provide legal protection to CPAs and their obligations, including protecting audit quality.

\section{Supervision toward CPAs and firms}

Supervision is focused on compulsory functions. According to [10], supervising is performing oversight for tasks and making sure they have been performed in accordance with existing rules.

Supervision can several approaches; one of them is inspection/audits. According to [4] regarding certified public accountants, supervision is performing an inspection of CPAs, firms, and its branches. In conducting supervisory activities, a Minister could assign another party on his or her. This policy is further explained in the technical Regulation of the Minister of Finance 154/PMK.01/2017 regarding the development and supervision of CPAs [11].

\section{E. Supervision Benchmark on CPAs and Firms in Other Countries}

Similar to the PPPK, the US Public Company Accounting Oversight Board (PCAOB) and Singapore's Accounting and Corporate Regulatory Authority (ACRA) provide supervision of CPAs and firms in their respective countries. Both institutions have similar functions as the PPPK, namely, to coordinate, formulate strategic policies with stakeholders, and act as a mentor and supervisor to the CPA profession.

\section{F. PPPK Inspection Guidelines}

According to [11], the inspection process for CPAs and firms is conducted by performing inspections on working papers up to presenting an inspection report to CPAs and firm's leadership. Inspection guidelines are explained in greater detail in the guideline formalized through [6], dated 4th of March, 2015 regarding inspection execution guidelines toward CPAs, firms, and/or its branches. This guideline was last revised in [7], dated 27th of April 2018 regarding inspection execution guidelines toward CPAs, firms, and/or its branches. This guideline is employed as a guide in conducting inspections, in the intention that it will improve inspection effectiveness due to effective supervision and mentoring of the CPA profession.

\section{G. Auditing Standards}

[12] classify auditing standards into four categories. First, an audit's purpose is to provide an opinion regarding the fairness of a firm's financial statement, ensuring it is free from material misstatements and in accordance to the applicable framework. Second, regarding an auditors' personal responsibilities, an auditor shall possess the required skills and competences, adhere to professional ethical regulations, maintain professional skepticism, and perform their responsibilities professionally. Third, auditors' actions in conducting an audit are related to (1) obtaining sufficient confidence that the financial statement is free from material misstatements, (2) ensuring adequate work planning and staffs supervision, (3) deciding and implementing materiality level, (4) identifying and assessing misstatement risks according to the entity's understanding and internal control environment, and (5) obtaining appropriate and sufficient audit evidence as a basis for declaring an opinion. Lastly, an auditor provides his or her professional opinion on a firm's financial statement through a written report. This report shows whether the financial statements have been presented fairly and in accordance with the basic framework of financial statement.

\section{H. International Organization of Profession Regulators}

To strengthen its supervision and oversight over CPAs and firms, the PPPK participates in international organizations, namely the International Forum of Independent Audit Regulators (IFIAR) and the ASEAN Audit Regulators Group (AARG).

IFIAR is an international organization whose mission is to serve the public interest and enhance investor protection by improving audit quality globally. IFIAR aims to share knowledge and experience among its member audit regulator institutions, which focus on supervising CPAs and firms and on ensuring audit quality [13]. On April 15th, 2013, Indonesia, represented by the PPPK, joined IFIAR as the 46th member. Indonesia's membership in IFIAR was then stipulated formally in [14].

AARG is an organization for regulators of CPAs and firms in the ASEAN region that have joined IFIAR. AARG was established in 2011, and PPPK joined the AARG as its 4th member [15]. The AARG's objective is in line with IFIAR, namely, to share knowledge and experience in supervising CPAs and firms to enhance audit quality. This forum offers a venue for dialog among regulators in ASEAN to improve CPAs' and firms' audit quality.

\section{RESEARCH METHOD}

\section{A. Data Collection Method}

This research uses both primary and secondary data. According to [16], primary data are data that contains information obtained from a first-hand source of information for a certain research purpose, whereas secondary data are data that refer to existing information sources.

This research applies three data collection methods. Observation was conducted by analyzing inspection guidelines documentation, followed by comparing the documentation with implementation of inspection guidelines. Interviews were conducted with the inspection team to determine the effectiveness of inspection guidelines implementation in supervising CPA and firms. Finally, a literature review was conducted by collecting literature relevant to this research, including books and journals related to inspection and accounting, CPAs, laws regulating CPAs, and other literature. 


\section{B. Data Analysis Method}

This research is a descriptive qualitative research. According to [16], qualitative data can be obtained from many sources, such as in-depth interviews, observations, documents, case studies, and electronic data. The problem definition serves as the foundation of qualitative research, by describing, translating, understanding significance, and interpreting the pattern of occurring phenomenon. This research uses the case study approach conducted at PPPK.

This research aims to evaluate the effectiveness of PPPK's supervision over CPAs and firms and the sufficiency of the PPPK's inspection guidelines compared with those of PCAOB and ACRA. In accordance with that objective, the researchers analyse the data using document observation of documents such as PPPK inspection guidelines, implementation documents, and other relevant documents. Interviews were also performed with the inspection team to determine the effectiveness of inspection guideline implementation. In addition, the researchers also compare PPPK inspection guidelines with PCAOB inspection guideline and the ACRA's inspection process, and other related sources as provided on the PCAOB and ACRA websites.

\section{Overview and Research Objects}

The PPPK is a unit under the Secretariat General of the Ministry of Finance, which supervises and oversees finance professions such as accountants, CPAs, valuers, actuaries, and other finance professions. PPPK is assigned to coordinate and implement the preparation of policy formulation, guidance, development, supervision, and information services regarding the finance professions, i.e., accountants, CPAs, accounting technicians, valuers, public valuers, actuaries, and other finance professions [17].

The object of this research is BPPA, especially in terms of the monitoring process over CPAs and firms.

TABLE II. COMPARISON OF OLD AND RECENT VERSION OF THE INSPECTION GUIDELINES

\begin{tabular}{|c|c|c|c|}
\hline No & $\begin{array}{c}\text { Old Version } \\
\text { (KEP-4/AP/2015) }\end{array}$ & $\begin{array}{c}\text { Recent Version } \\
\text { (KEP-17/PPPK/2018) }\end{array}$ & Reccomendation \\
\hline 1. & $\begin{array}{l}\text { Does not regulate the qualification of the } \\
\text { inspection team. }\end{array}$ & $\begin{array}{l}\text { Does not regulate the specific qualification for } \\
\text { every level of the inspection team. }\end{array}$ & $\begin{array}{l}\text { Specific qualification for every level of } \\
\text { inspection team. }\end{array}$ \\
\hline 2. & $\begin{array}{l}\text { Regulates the considerations in formulating } \\
\text { RPT. }\end{array}$ & $\begin{array}{l}\text { The RPT formulation does not include } \\
\text { components related to inspection result. }\end{array}$ & $\begin{array}{l}\text { Include the considerations related output } \\
\text { (inspection result). }\end{array}$ \\
\hline 3. & $\begin{array}{l}\text { Regulate the criteria of delay and refusal of } \\
\text { inspection. }\end{array}$ & $\begin{array}{l}\text { Does not regulate the delay and refusal of } \\
\text { inspection. }\end{array}$ & $\begin{array}{l}\text { Regulate the mechanism and criteria of } \\
\text { delay and refusal of inspection. }\end{array}$ \\
\hline 4. & $\begin{array}{l}\text { The time period of completion of inspection } \\
\text { report are regulated in key performance } \\
\text { indicators (KPI). }\end{array}$ & $\begin{array}{l}\text { Does not specifically regulates the time period of } \\
\text { inspection report completion. }\end{array}$ & $\begin{array}{l}\text { Include the time period of inspection report } \\
\text { completion in the inspection guidelines. }\end{array}$ \\
\hline 5. & $\begin{array}{l}\text { The guidelines regulate the flow of sanction } \\
\text { recommendation. }\end{array}$ & $\begin{array}{l}\text { Does not include the flow of sanction } \\
\text { recommendation. }\end{array}$ & $\begin{array}{l}\text { Include the flow of sanction } \\
\text { recommendation. }\end{array}$ \\
\hline 6. & $\begin{array}{l}\text { The documentation of working paper are } \\
\text { regulated in the time period set in the KPI }\end{array}$ & $\begin{array}{l}\text { Does not specifically regulate the time period of } \\
\text { working paper completion. }\end{array}$ & $\begin{array}{l}\text { Regulate the time period of every team in } \\
\text { completing working papers. }\end{array}$ \\
\hline
\end{tabular}

\section{DISCUSSION}

\section{A. General Analysis of PPPK Inspection of CPAs and Firms}

In conducting inspections, the BPPA acts according to inspection guidelines. At the time of this study, the inspection guidelines had been amended with [6], dated March 4, 2015, then amended through [7] dated April 27, 2018. These changes were made to conform with developments in regulations and professional standards. Thus, he old and recent versions of inspection guidelines need to be compared.

In general, the differences between the older and more recent version are not significant. First, the annual inspection plan (Rencana Pemeriksaan Tahunan, hence RPT) is formulated by analyzing the inspection risk profile related to the quality and risk of Principles of Identifying Service Users through a sectoral risk assessment set by PPPK. Second, the monitoring of the follow-up on the inspection report.

Based on the researcher's analysis, in general, the recent inspection guidelines are sufficient, but need improvement in some areas. The old version did not regulate the criteria/qualification of the inspection team, but the recent version stipulates criteria for the team leader. However, no regulations have been promulgated regarding the experience of inspection personnel, specific competencies in the particular industry, or requirements for technical competency improvement.

The older version of RPT considered the number of effective working days in a year, the scope of inspection, and the budget. The more recent RPT formulation considers risk as well as gives detailed consideration to factors such as the risk profile related to Principles of Identifying Service Users. However, the RPT formulation does not include every factor of audit quality, such as output components (result of inspection performed). According to the inspection team, the inspection risk profile analysis shall consider the result of inspections performed. Information on the inspection result record, which can be used as risk profile analysis, will be obtained from the analysis of inspection result.

The old version contains a regulation related to criteria for delaying an inspection. However, the new version does not include such criteria. According to the researchers, the inspection guidelines should include a mechanism and criteria for a delay with determined considerations.

The old version provides a time period for the completion of the inspection report. However, the new version leaves the time period of inspection report completion up to the submission to the CPAs and firms rather than give a specific 
timeframe. The researchers suggest that the guidelines should include a specific time period for completion and reporting of inspection results in order to ensure that the inspection team is well-controlled when performing their tasks.

The old version regulates sanction recommendations as part of its follow-up on inspection results. The new version, however, does not include regulations related to sanction recommendations as part of the flow of the formulation. The researchers therefore suggest that such regulations related to sanction recommendations should be included as a reference and reminder for the team when carrying out its tasks.

The old version states that working papers shall be fully prepared within the time period set in the KPI. The new version, however, states detailed documentation rules, including those relating to the inspection database, but does not discuss the time period for completing working papers. According to the researchers, it is necessary to set a timeframe within which all teams need to complete their inspection working papers.

\section{B. BPPA Human Resources (HR) Recruitment and Mutation Process}

The BPPA HR recruitment process is conducted according to the common practices of civil servant recruitment in the Ministry of Finance, where each proposal is submitted by each unit. According to the researchers, the proposing unit (PPPK) shall mention special requirements for BPPA inspection personnel candidates during the recruitment process.

Based on observations and interviews conducted by the researchers, there is no Standard Operating Procedure (SOP) related to the mutation process. According to researchers, it is necessary to develop a SOP related to the mutation process in the PPPK, with clear consideration, especially of the BPPA. Therefore, the competencies between inspection personnel and auditee shall be on a par.

\section{Adequacy of Inspection Personnel}

According to [18], there are 1,388 registered CPAs and 444 firms. This ratio is relatively small compared to the number of inspection personnel available (19). The ratio of inspection personnel compared to the number of CPAs and firms is as follows.

Table 3 shows that 1 inspection personnel is in charge of 73 CPAs and 23 firms. The KPI of inspection personnel is that 1personnel shall inspects $10 \mathrm{CPAs}$ in a year. The researchers suggest an increase in the number of inspection personnel to allow the inspecting team to perform optimally.

Table 4 shows that the average interval between CPA inspections is 16 years, and 6 years for firm inspection. This interval is relatively long and can be attributed to the insufficiency of BPPA inspection personnel, which causes a backlog in the inspection process. The researchers suggest that the number of inspection personnel for CPAs and firms should be increased.

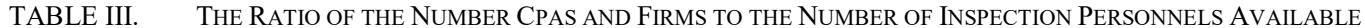

\begin{tabular}{|c|c|c|}
\hline $\begin{array}{l}\text { The number of CPA compared to the number } \\
\text { of inspection personnel }\end{array}$ & $\begin{array}{l}=\frac{\text { the number of public accountants }}{\text { the number of inspection personnel }} \\
=\frac{1388}{19} \\
=73 \mathrm{CPAs} / \text { personnel }\end{array}$ & The KPI of inspecting staffs: 10 \\
\hline $\begin{array}{l}\text { The number of firms compared to the } \\
\text { number of inspection personnel }\end{array}$ & $\begin{array}{l}=\frac{\text { the number of firms }}{\text { the number of inspection personnel }} \\
=\frac{444}{19} \\
=23 \text { firms/personnel }\end{array}$ & CPAs/personnel \\
\hline
\end{tabular}

TABLE IV. THE TURNOVER RATIO OF INSPECTION TOWARDS CPAS AND FIRMS

\begin{tabular}{|c|c|c|}
\hline Year & $\begin{array}{c}\text { The number of inspection towards CPAs } \\
\text { (periodical and SPM) }\end{array}$ & $\begin{array}{l}\text { The number of inspection towards firms (periodical } \\
\text { and SPM) }\end{array}$ \\
\hline 2015 & 83 Pas & 55 firms \\
\hline 2016 & 85 Pas & 60 firms \\
\hline 2017 & 90 Pas & 77 firms \\
\hline Inspection plan of 2018 & 80 Pas & 80 firms \\
\hline Total & 338 Pas & 272 firms \\
\hline \multirow[t]{2}{*}{ Average of inspection per year } & \multicolumn{2}{|l|}{$=$ the number of public accountants or firms inspected in 4 years } \\
\hline & $\begin{array}{l}=\frac{338}{4} \\
=85 \text { PAs } / \text { year }\end{array}$ & $\begin{array}{l}\frac{272}{4} \\
=68 \text { firms/year }\end{array}$ \\
\hline \multirow[t]{2}{*}{ Inspection turnover } & \multicolumn{2}{|l|}{$\frac{\text { the number of public accountants or firms per May } 2018}{\text { Average inspection per year }}=$} \\
\hline & $\begin{array}{l}=\frac{1388}{85} \\
=16 \text { years }\end{array}$ & $\begin{array}{l}\frac{444}{68} \\
=6 \text { years }\end{array}$ \\
\hline
\end{tabular}


TABLE V. THE COMPARISON OF INSPECTION GUIDELINES IMPLEMENTATION IN PPPK

\begin{tabular}{|c|l|l|l|}
\hline No & \multicolumn{1}{|c|}{ Inspection Guidelines } & Implementation (Current Condition) & \multicolumn{1}{c|}{ Recommendation } \\
\hline 1. & $\begin{array}{l}\text { Inspection team shall prepare } \\
\text { inspection program. }\end{array}$ & $\begin{array}{l}\text { Inspection program related to the technical } \\
\text { aspect is not implemented. }\end{array}$ & $\begin{array}{l}\text { Prepare inspection program consistent to the scope } \\
\text { of inspection. }\end{array}$ \\
\hline 2. & $\begin{array}{l}\text { CPAs and firms may deliver written } \\
\text { responses on the letter regarding the } \\
\text { inspection result (SSHP). }\end{array}$ & $\begin{array}{l}\text { Timeframe where CPAs and firms are } \\
\text { allowed to deliver written responses on } \\
\text { SSHP is not implemented. }\end{array}$ & $\begin{array}{l}\text { Regulate the a clear timeframe for the responses } \\
\text { submission on the SSHP. }\end{array}$ \\
\hline 3. & $\begin{array}{l}\text { Short version of inspection report is } \\
\text { delivered to the CPAs and firms. }\end{array}$ & $\begin{array}{l}\text { Both short and complete version of } \\
\text { inspection report is delivered to the CPAs } \\
\text { and firms. }\end{array}$ & $\begin{array}{l}\text { Include in the guidelines that the inspection report } \\
\text { delivered to the CPAs and firms are both short and } \\
\text { complete version. }\end{array}$ \\
\hline 4. & $\begin{array}{l}\text { The monitoring of action plan } \\
\text { includes detailed procedures. }\end{array}$ & $\begin{array}{l}\text { The implementation of the new guidelines } \\
\text { will be started on the 2018. }\end{array}$ & $\begin{array}{l}\text { The implementation of the new guidelines shall be } \\
\text { applied started from the previous year inspection } \\
\text { results as most of the monitoring results has been } \\
\text { received and they need to be followed-up. }\end{array}$ \\
\hline
\end{tabular}

TABLE VI. COMPARISON OF GENERAL ASPECTS IN THE INSPECTION OF CPAS AND FIRMS

\begin{tabular}{|c|l|l|l|l|}
\hline No & \multicolumn{1}{|c|}{ Topic } & \multicolumn{1}{c|}{ PPPK } & \multicolumn{1}{c|}{ PCAOB } & \multicolumn{1}{c|}{ ACRA } \\
\hline 1. & Document review method & In the firms' office. & In the firms' office. & In the firms' office. \\
\hline 2. & Inspection turnover & Not specifically regulated. & Minimum once every three years. & No sufficient information. \\
\hline 3. & Inspection team experiences & Not specifically regulated. & $\begin{array}{l}\text { More or less twelve years of } \\
\text { experience in firms. }\end{array}$ & $\begin{array}{l}\text { More or less ten years of } \\
\text { experience in firms. }\end{array}$ \\
\hline
\end{tabular}

c. (Source: PPPK data, https://pcaobus.org/, https://www.acra.gov.sg/Public_Accountants/, which is reprocessed)

\section{Analysis of the Implementation of PPPK Inspection Guidelines}

In analyzing the implementation of inspection guidelines, the researchers compared the guidelines with their implementation. During the analysis, the researchers observed and interviewed inspection personnel to complete the information collected. The researchers only present an analysis on the comparison of inspection procedures that differ from the implementation. Implementations that conform with the guidelines are not included.

In general, PPPK Inspection Guidelines have been well implemented. However, weaknesses are present in several areas.

The inspection guidelines are supported with an inspection working paper template, but there is no inspection program template in accordance with the inspection scope for technical aspects. According to the researchers, the inspection program shall be consistent with the scope of the inspection guidelines, including the audit program used by the auditor in conducting the inspection.

According to the inspection guidelines, CPAs and firms may provide a SSHP written response prior to discussing the inspection report. However, document observation revealed that the inspection guidelines do not fully provide opportunity/adequate time for CPAs and firms to provide a SSHP written response prior to discussing the inspection report. According to the researchers, a clearer timeframe should be specified, such as a time limit for SSHP submission and the period for CPAs and firms to provide a SSHP written response prior to discussing the inspection report.

The inspection guidelines state that the short version of the inspection report is signed by the Head of the PPPK and delivered to both CPAs and firms. However, the document observations and interviews conducted by the inspection team, revealed that the short version inspection report is in fact delivered without being signed by the Head of the PPPK. According to the examiner team, inspection guidelines should be improved regarding this issue.

Implementation of the action plan procedure in accordance with the inspection guidelines will start in 2018 . In general, improvements to the follow-up of inspection result monitoring guidelines are well-performed. According to the researchers, monitoring should also be implemented for the prior year's inspection result because most monitoring results have been received by PPPK and should be followed up. This is done in order to provide value-added to the examined CPAs and firms.

\section{E. Comparison of PPPK Inspection Guidelines with those of PCAOB and ACRA}

In general, the inspection processes followed by the PPPK, PCAOB, and ACRA are relatively similar. The documents reviews are performed in the firms' office. However, in certain cases, PCAOB document reviews can be performed in the PCAOB office.

The PPPK does not specifically regulate inspection turnover. The researchers could not find sufficient information on inspection turnovers in ACRA. Meanwhile, in the PCAOB, reviews are performed every three years.

The PPPK does not specifically stipulate the requirements for becoming an inspection personnel in terms of prior experience as a practitioner in firms. However, the guidelines require a CPA certification and three years' experience in the field of inspection. The PPPK's recruitment procedure follows the recruitment system established by the Ministry of Finance. In contrast, the PCAOB requires inspection personnel to have a minimum of 12 years of experience as a practitioner in firms. Similarly, ACRA 
requires a minimum of 10 years of experience in firms for inspection personnel.

Regarding information requests outside of CPAs and firms, differences in the scope/authority of inspections exist between PPPK and PCAOB. Indonesia has its own regulations related to the PPPK's authority in the areas of supervision and oversight. According to Article 29 of Law $5 / 2010$, the PPPK's authority is limited to supervising professions such as CPAs, firms, and firms' branches, whereas the PCAOB is allowed to communicate with the head of the audit committee. However, the researchers could not obtain sufficient information regarding the reviews conducted by ACRA.

In both PPPK and PCAOB, the preparation of inspection report drafts is conducted through internal staff discussions and accommodating the inspection team, enabling them to amend the report when responses from CPAs/firms are valid and adequate. The difference occurs before the final inspection report is published. The PCAOB discusses the inspection report and confers approval through majority vote by the PCAOB Board (which is not part of the inspection team that directly inspects CPAs and firms). The final inspection report will be delivered to the firms and SEC, which will then publish the inspection report on their website. In contrast, detailed information could not be obtained for the procedures followed by ACRA. However, for inspection by the PAOC, the findings (if any) will be reviewed by the PMSC, whose members are both practitioners and non-practitioners. Then, the PAOC will decide the result of the review=. According to the researchers, the preparation of the final inspection result shall involve parties who are not directly involved in the inspection, such as quality control, so that the conclusions reached will be more objective.

PCAOB may publish the final inspection results on its website with approval from the CPAs and firms, but the PPPK has its own regulations related to information confidentiality. Article 29 of [4] states that the Minister of Finance, in this case the PPPK, is obliged to maintain confidentiality of information obtained from CPAs and/or associated parties. Further, article 51 of [4] states that the inspector assigned by the Minister should keep any information obtained during inspection process and final inspection report confidential from unauthorized parties. ACRA does not publish inspection reports on their website but do publish PMP reports containing the regulatory and inspection scope, inspection findings on CPAs and firms, and the requirements that should be fulfilled by CPAs. According to the researchers, the PPPK shall publish their inspection findings regularly on their website. Such publication may be useful for CPAs and firms as a reference when completing their audit working papers, especially during subsequent engagements, which will contribute to the improvement of audit quality.

TABLE VII. COMPARISON OF INSPECTION GUIDELINES OF PPPK, PCAOB, AND ACRA

\begin{tabular}{|c|l|l|l|}
\hline NO & \multicolumn{1}{|c|}{ PPPK } & \multicolumn{1}{|c|}{ PCAOB and ACRA } & Conclusion \\
\hline 1. & $\begin{array}{l}\text { PPPK cannot inquire information } \\
\text { except from the audit team, CPAs, } \\
\text { and firms. }\end{array}$ & $\begin{array}{l}\text { As a part of review process, PCAOB may interview } \\
\text { the head of audit committee. } \\
\text { The researcher cannot not find sufficient informa- } \\
\text { tion related to the information inquiry in ACRA. }\end{array}$ & $\begin{array}{l}\text { Information inquiries to the CPAs and firms } \\
\text { are basically similiar to PPPK. }\end{array}$ \\
\hline 2. & $\begin{array}{l}\text { The procedure of inspection report } \\
\text { preparation is conducted through } \\
\text { internal discussion of Inspection } \\
\text { Team. }\end{array}$ & $\begin{array}{l}\text { Inspection report is discussed and approved via } \\
\text { majority vote amongst the PCAOB Board. } \\
\text { ACRA inspection by Public Accountants Oversight } \\
\text { Committee (PAOC), the findings (if any) will be } \\
\text { reviewed by Practice Monitoring Sub Committee } \\
\text { (PMSC). }\end{array}$ & $\begin{array}{l}\text { The } \\
\text { includes the Teams which are not directly } \\
\text { inved in the inspection. }\end{array}$ \\
\hline 3. & $\begin{array}{l}\text { PPPK does not publish the } \\
\text { inspection reports in the website. }\end{array}$ & $\begin{array}{l}\text { PCAOB publish the final inspection reports in the } \\
\text { website. } \\
\text { ACRA does not publish inspection reports in the } \\
\text { website. }\end{array}$ & $\begin{array}{l}\text { PPPK needs to regularly publish common } \\
\text { inspection findings of CPAs and firms in the } \\
\text { website. }\end{array}$ \\
\hline
\end{tabular}

(Source: PPPK data, https://pcaobus.org/, https://www.acra.gov.sg/Public_Accountants/, which is reprocessed)

\section{RESULTS}

\section{A. Conclusions}

This research has evaluated the effectiveness of PPPK supervision of CPAs and firms and sought to understand whether the PPPK's inspection guidelines are effective and practicable compared with those of PCAOB and ACRA.

In general, the PPPK guidelines are sufficiently feasible because they regulate significant aspects of the inspection of $\mathrm{CPAs}$ /firms. The inspection guidelines also provide adequate guidance regarding considerations related to the preparation of RPT and sufficient procedures for the monitoring of follow-up of inspection results related to the action plan submitted by CPAs and firms. However, some issues have been identified that require improvement. These include more specific requirements for the inspection team, including inspection result factors in the inspection risk profile analysis related to the audit quality, criteria on delaying inspections, flow on sanctions recommendation, and the timeframe for the inspection report preparation.

In general, PPPK inspections of CPAs and firms can be considered adequately effective because most inspection phases are well-implemented. Points that needs to be improved are related to follow-up of the inspection results of action plans. An improvement to the inspection guidelines could include adding an inspection program template and a timeframe for CPAs and firms to submit written responses on SSHP.

PPPK inspection guidelines can therefore be considered sufficiently effective and practicable when compared with those of the PCAOB and ACRA. However, the comparison highlighted several further issues that need to be adjusted in the PPPK inspection guidelines: (1) review the regulations including teams that are not directly involved in the inspection, and (2) add a regulation related to regular 
publication of common inspection findings on the agency website.

Several points related to the HR in BPPA were also identified for consideration. First, there is no SOP related to the mutation process. Second, the lack of BPPA inspection personnel has led to a backlog in the inspection of CPAs and firms.

\section{B. Suggestions}

It is therefore indicated that the PPPK shall improve the inspection guidelines. Some points that need attention are the qualification requirements for inspection teams, inspection result consideration in the inspection risk profile analysis related to the audit quality, criteria for delaying inspection, flow of sanction recommendation preparation, timeframe of SSHP submission and the period for CPAs and firms to provide SSHP written responses prior to inspection report discussions, involvement of non-directly-related teams in the inspection report preparation, and regular publication of common inspection findings on the agency website.

PPPK shall follow-up the action plan received and on the unfinished action plan based on the applicable guidelines and regulations.

Regarding the HR in BPPA, PPPK shall increase the number of inspection personnel with appropriate qualifications in accordance with their duties and responsibilities.

PPPK shall formulate a SOP related to their recruitment policies and employee mutation, especially inspection personnel mutation.

\section{Implication of research for the practitioner (CPAs and firms)}

It is intended for this research to be useful in assisting practitioners in enhancing their knowledge of the PPPK inspection process, to prepare appropriate working papers in accordance with the laws and professional standards, and to improve their understanding of CPAs and firms to better follow-up on the inspection results and recommendations.

\section{Implication of research for academics}

This research is intended to be useful for academics in terms of adding to the literature on the inspection process by regulators (PPPK) toward CPAs and firms and to enhance the body of knowledge on the effectiveness of PPPK supervision of CPAs and firms, as well as whether PPPK inspection guidelines are effective and practicable compared with those followed by the PCAOB and ACRA.

\section{REFERENCES}

[1] International Accounting Standards Board, "International financial reporting standards conceptual framework for financial reporting (conceptual framework), 2018. http://www.ifrs.org.

[2] L. DeAngelo, "Auditor size and audit quality," J. Account. Econ., vol. 3, pp. 183-199, 1981.
[3] Institut Akuntan Publik Indonesia, Standar audit SA 230 dokumentasi audit, Jakarta: Penerbit Salemba Empat, 2015.

[4] Government of the Republic of Indonesia, Law number 5 of 2011 concerning public accountants, 2011.

[5] Ministry of Finance, "Decree of the minister of finance of the republic of indonesia number 447 / km.1 / 2017 concerning revocation of permission of public accountant achmad rodi kartamulia," 2017. http://www.pppk.kemenkeu.go.id/Sanksi/Details/2 5.

[6] Pusat Pembinaan Profesi Keuangan, "Decree of the head of pusat pembinaan akuntan dan dan jasa penilai nomor: kep-4/ap/2015 concerning inspection guidelines for public accountants," KAP and/KAP branches, 2015.

[7] Pusat Pembinaan Profesi Keuangan, "Decree of the head of pusat pembinaan profesi keuangan nomor: kep-17/pppk/2018 dated 27 april 2018 concerning inspection guidelines for public accountants," KAP and/KAP branches, 2018.

[8] M. C. Jensen and W. H. Meckling, "Theory of the firm: managerial behavior, agency cost, and ownership structure," J. Financ. Econ., vol. 3 pp. $305-360,1976$.

[9] W. R. Scott, Financial accounting theory, 5th ed., Canada Prentice Hall, 2009.

[10] S. C. Certo, Supervision concept and skill building, 8th ed., McGraw Hill, 2013.

[11] Ministry of Finance, Regulation of the Minister of Finance Number 154 of 2017 regarding the Development and Supervision of Certified Public Accountants, 2017.

[12] A. A. Arens, R. J. Elder, and M. S. Beasley, Auditing and assurance services: An integrated approach, 14th ed., New Jersey: Pearson Prentice Hall, 2017.

[13] International Forum of Independent Audit Regulators, 2018. https://www.ifiar.org/about/.

[14] Presidential Decree Number 38 of 2014 concerning the determination of Indonesian membership in the International Forum of Independent Audit Regulators forum, http://pih.kemlu.go.id/files/Keppres Nomo r 38 Tahun 2014 PENETAPAN KEANGGOTAAN INDONESIA _PADA_INTERNATTIONAL_FORUM_OF_INDEPENDENT_AUDI $\bar{T}$ _REGÜLATIONS.pdf.

[15] Ministry of Finance, "ASEAN Audit Regulators Group (AARG)," 2016. https://www.kemenkeu.go.id/media/3539/kp_aarg_200116.pdf.

[16] U. Sekaran and R. Bougie, Research methods for business, United Kingdom: Jhon Wiley \& Sons Ltd, 2013.

[17] Pusat Pembinaan Profesi Keuangan, "History of pusat pembinaan profesi keuangan," 2018. http://www.pppk.kemenkeu.go.id/Profil/De tails $/ 3$.

[18] Pusat Pembinaan Profesi Keuangan, "Data growth of CPAs, firms and inspection personel as of May 2018," 2018.

Accounting and Corporate Regulatory Authority (ACRA). "Practice Monitoring Program Reports (PMP)," 2017. https://www.acra.go v.sg/Public_Accountants/Practice_Monitoring_Programme/PMP_Pro cess/ Accessed on December 29, 2017.

Institut Akuntan Publik Indonesia, "Standar profesional akuntan publik," Jakarta: Penerbit Salemba Empat, 2015.

Public Company Accounting oversight board (PCAOB) inspection guidelines, 2012. https://www.thecaq.org/sites/default/files/guidetop caobinspections.pdf. 